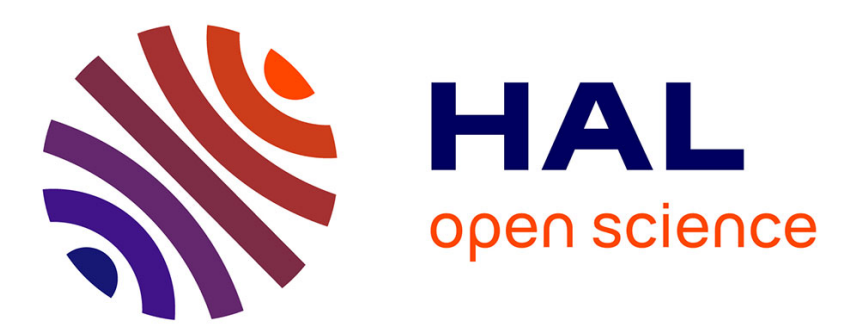

\title{
The heterogeneity of humus profiles and earthworm communities in a virgin beech forest
}

Jean-François Ponge, Laurent Delhaye

\section{To cite this version:}

Jean-François Ponge, Laurent Delhaye. The heterogeneity of humus profiles and earthworm communities in a virgin beech forest. Biology and Fertility of Soils, 1995, 20 (1), pp.24-32. 10.1007/BF00307837 . hal-00505505

\section{HAL Id: hal-00505505 \\ https://hal.science/hal-00505505}

Submitted on 1 Sep 2010

HAL is a multi-disciplinary open access archive for the deposit and dissemination of scientific research documents, whether they are published or not. The documents may come from teaching and research institutions in France or abroad, or from public or private research centers.
L'archive ouverte pluridisciplinaire HAL, est destinée au dépôt et à la diffusion de documents scientifiques de niveau recherche, publiés ou non, émanant des établissements d'enseignement et de recherche français ou étrangers, des laboratoires publics ou privés. 


\title{
The heterogeneity of humus profiles and earthworm communities in a virgin beech forest
}

\author{
J.F. Ponge $\cdot$ L. Delhaye
}

\begin{abstract}
Thirty sites, encompassing a range of soil and vegetation conditions in the biological reserve of La Tillaie (Fontainebleau Forest, France) were investigated in April 1992. Beech (Fagus sylvatica L.) was the dominant tree species, with several developmental phases forming the forest patchwork. Sessile oak [Quercus petraea (Mattus.) Liebl.] was present but only as old relictual individuals. Gaps in the canopy cover were abundant, mostly caused by wind storms 2 years previously. The next most recent storm was 25 years before, resulting in distinct patches of full-grown trees. Humus profiles were classified and compared with the distribution of earthworm communities, canopy cover, and soil types. Geomorphology was responsible for the main part of the observed variation. Absence of lime in the substrate and direct contact with a sandstone stratum near the ground surface was associated with the absence of earthworms and the appearance of an $\mathrm{OH}$ horizon (moder humus). Elsewhere, earthworms were present and humus profiles did not display any OH horizon (mull or mull-like moder humus), but species composition was variable and strongly influenced by the thickness of the superficial sand deposit overlying limestone. On a thick (1 m or more) sandy substrate earthworm communities were dominated by epigeic species together with the anecic Lumbricus terrestris $\mathrm{L}$. The species richness was higher on a shallower sandy substrate $(50 \mathrm{~cm})$ where lime was more accessible to tree roots and burrowing animals. The influence of the forest cycle of beech was visible in the latter case (covering most of the area), with an increase in the thickness of the OL and OF horizons and a decrease in endogeic earthworm populations during the phase of intense growth of beech. This fall in burrowing activity was apparent in gaps created by wind storms and fungal diseases within mature stands as early as 2 years after the fall of the trees.
\end{abstract}

J.F. Ponge ( $\varpi^{\prime}$ · L. Delhaye, Museum National d'Histoire Naturelle, Laboratoire d'Ecologie Générale, 4 avenue du Petit-Château, F-91800 Brunoy, France 
Key words Virgin forest · Forest cycle · Geomorphology · Heterogeneity · Earthworms · Humus type

\section{Introduction}

Previous work on mountain spruce forests (Bernier 1992; Bernier et al. 1993; Bernier and Ponge 1993, 1994; Ponge et al. 1994) has demonstrated that parallel changes occur in vegetation, humus profiles, and soil animal com-munities throughout the forest cycle, with alternation between phases of accumulation and incorporation of litter. These effects might be thought important for regeneration when tree seedlings are not tolerant of humus type. This is the case for spruce (Weissen 1979) and also for beech trees (Weissen 1986; Weissen et al. 1986). Amelioration of humus conditions under adult trees, preparing for the installation phase, has been demonstrated both in managed (Page 1968) and in native forests (Page 1974).

A preliminary study was conducted in a virgin beech forest to discern whether such changes occur in the case of beech and whether they can be separated from differences due to heterogeneity of the parent material. Thirty sites were investigated in the biological reserve of La Tillaie (Fontainebleau forest near Paris), encompassing the whole range of soil and vegetation conditions. Humus profiles and earthworm communities were sampled in April 1992.

The biological reserve of La Tillaie (50 km south of Paris, France), free of management since the beginning of the 16th century, has been studied time and again (Lemée 1990a). The changes that took place in the passage from the ancient woodland where oak was favoured by man to the present beech steady state and in the regeneration of the latter ecosystem have been deduced both from synchronic (Lemée 1978, 1985, 1987a, b, 1989) and diachronic (Guillet and Robin 1972; Jacquiot et al. 1973; Lemée 1981, 1990b; Faille et al. 1984a, b) analyses. The soil and vegetation types and canopy cover have been mapped (Bouchon et al. 1973) and long-term studies have been set up to follow the changes occurring in plant cover and forest architecture over time (Van Baren and Hilgen 1984; Koop and Hilgen 1987).

Studies on the forest cycle of virgin forests may be complicated by the heterogeneity of the soil substrate. This is particularly evident in the case of soil animal communities (Arpin et al. 1984) and humus profiles (Duchaufour 1980; Toutain 1987). In the present study we tried to distinguish between variations due to 
geomorphological diversity and others due to forest dynamics.

\section{The sites}

The study area has been described by Lemée (1978). The soil is sandy, with 0-3\% clay and 2-5\% silt particles in the A horizon (Robin 1970), varying from leached only to podzol soil according to the nomenclature by Duchaufour (1991). The vegetation comprises beech trees, varying in age and density, with oak present as a few senescent trees. Regeneration areas include only beech. Phases of the forest cycle have been recognized, as in other virgin forests, according to the nomenclature of Oldeman (1990), the delineation of the different eco-units being based on observations that regeneration of beech (when effective) occurs mainly when the trees are in a senescent state or dead. In some cases declining trees are always present, together with young individuals of the next generation. In others (when healthy adult trees were wind-thrown) gaps occurred before regeneration took place. The appearance of wide gaps may be delayed in time by successive storms, the first smaller gaps beginning to be filled with the growth of lateral branches of standing trees, enlarging when these trees died in turn. Trees have never been felled, and dead wood has never been removed from the ground. The biological reserve of La Tillaie covers 33.74 ha. This woody area is located at the centre of the Fontainebleau forest, $50 \mathrm{~km}$ south-east of Paris. The ground is fairly level, the elevation ranging from 134.8 to $139.4 \mathrm{~m}$ above sea level. The parent material is wind-blown sand directly overlying a sandstone base or an intercalary stratum of friable limestone. In the latter case the thickness of the sand cover is variable, ranging from 30 to $200 \mathrm{~cm}$ (Robin 1970).

Table 1 indicates the main features of the 30 sites investigated. The age of the trees has not been determined but two major events (storms in 1967 and 1990) are reflected in the presence of numerous thickets of actively growing trees (aggradation phase) and numerous gaps without any vegetation (zero event, before the innovation phase). Some ancient gaps have been invaded by bracken fern [Pteridium aquilinum (L.)], sparse regeneration when present taking place only at their periphery. The smaller gaps (fall of individual trees) are often filled with branches growing from adjacent trees. In this case regeneration either did not take place or was aborted. Some particular cases were investigated, such as the development of beech clonal populations (suckers) issuing from the infrequent fall by wind of a pole-stage tree. Ground vegetation is sparse. The micro-scale distribution of graminaceous species (mainly Melica uniflora Retz.) in the gaps or of dwarf shrubs such as Ruscus 
aculeatus $\mathrm{L}$. under adult trees was not taken into account in the present study, although it is known to influence humus properties (Lemée 1975; Faille 1975a, b, 1977a, b). Each site was sampled repetitively (three samples for humus description, six for earthworm communities), the choice and size of study sites being based only on architectural and geomorphological features. Thus no nesting of study scale was attempted, the present work being aimed only at separating effects of the forest cycle from those of site conditions. The local influence of understory plant species will be the subject of a further study.

\section{Materials and methods}

Description of humus profiles

In each site three sample plots were selected randomly, and the soil was first trenched with a shovel down to 15 $\mathrm{cm}$. Then a vertical profile was gently dressed with a sharp knife. The profiles were described by thickness of the OL, OF, OH horizons, depth of the A horizon (nomenclature according to A.F.E.S. 1992) and colour parameters (colour, chroma, value on Munsell soil colour charts) at 3,6, and $9 \mathrm{~cm}$ in depth below the litter horizons. The presence or absence of white-rot fungi in the beech leaves (OL and OF horizons) was roughly estimated with the naked eye (coded as 1 or 0 ). Thus 14 measurements were taken on each humus profile.

Description of earthworm communities

Each earthworm sampling area was $1.5 \mathrm{~m}^{2}$ (six replicates randomly selected, each $0.5 \mathrm{~m}^{2}$ ) and was prepared by spraying a repellent solution on the bare ground after having sorted the OL and OF horizons by hand. The chemical repellent used was formalin, applied at $10^{-3}, 1.5 \times 10^{-3}$, then $2 \times 10^{-3}$ concentrations at 10 -mn intervals. The worms were immediately fixed in pure formalin then transferred to the laboratory. Identification was made under a dissecting microscope. The nomenclature used was that of Sims and Gerard (1985). The species were classified into litter-dwelling and soil-dwelling species. The first group was considered synonymous with the epigeic group of Bouché (1972), but the second group included both endogeic and anecic species sensu Bouché (1972). The species are listed in Table 2, with an indication of their typical habitat according to literature. In the present study 
site the sandy nature of the soil allowed the worms very easy vertical movement. Thus they were able to change habitat frequently. Most worms (including the so-called litter-dwelling species) were found living in the mineral soil, from which they were expelled very easily by formalin (no worm was found after hand-sorting of the mineral soil once the extraction was completed). Another particular feature was the unexpected lack of body pigmentation in Dendrodrilus rubidus and Dendrobaena pygmaea, two litter-dwelling species that were invariably found burrowing into the A horizon.

\section{Statistical treatment}

Humus profiles, described by their 14 morphological measurements, were ordinated using correspondence analysis (Greenacre 1984). The data were transformed by reweighting and focusing them so that the mean equalled 10 and the variance equalled 1 for each measurement. Two variates were associated with each measurement, the original value (transformed as above) and its complement to 20. Thus, on the graphs one point was associated with the higher values of a given measurement, the other with the lower values. Between the two a gradient from lower to higher values was displayed. Earthworm densities and biomasses and variates describing vegetation, soil types, and geomorphology were added as additional variates, without any influence on the ordination of humus profiles but giving weight to interpretation of the axes.

The humus measurements and densities and biomass of earthworm species and categories were compared between the different sites. These were grouped according to geomorphological features or phases of the forest cycle. Heterogeneity among means was tested by one-way analysis of variance (Sokal and Rohlf 1969; Rohlf and Sokal 1969) with the different samples taken in a given group as replicates. The different sites (Table 1) were chosen randomly within the study area and immediately classified into sylvogenetical or geomorphological groups with the help of tree architecture (Oldeman 1990) and maps of the study area (Bouchon et al. 1973). In each site, six (for earthworms) and three (for humus profiles) sample plots were selected randomly. It might have been necessary to test the differences between sites within a given group; in this case the residual error would have been the variation within sites. Since we had no reason to expect the variation between sites (within a group) to be greater than the variation within sites, all samples within a group were considered as replicates, thus taking the risk of increasing the residual error but providing more confidence in the answer to the 
question is there a geomorphology or a forest cycle effect on humus profiles and earthworm communities in the study area? Significant differences between means were calculated a posteriori using the Student-Newman-Keuls procedure for unbalanced groups (Sokal and Rohlf 1969; Rohlf and Sokal 1969). Earthworm densities and biomasses were transformed into $\log (x+1)$ in order to ensure that the effects were additive. All earthworm species were tested, except Eisenia fetida and Lumbricus eiseni, which were each represented by only one individual in the data matrix.

\section{Results and discussion}

Influence of geomorphology

Ordination of the 90 samples by correspondence analysis (Fig. 1) indicated that the parent geology was the main factor in the variation of humus types. Three groups were easily separated on the basis of morphological features. The humus profiles in sites with free access to lime were separated from the two other groups by axis 1 . They were characterized by a thin A horizon, light yellow in colour, and the absence of the $\mathrm{OH}$ horizon (acid mull humus; Toutain 1981). The two other groups were separated by axis 2 according to the presence or absence of a sandstone layer at the base of the superficial sand cover. When sandstone was present the humus profiles were characterized by the presence of an $\mathrm{OH}$ horizon (moder humus; Toutain 1981) and a dark reddish A horizon. When limestone was present, but under a deep sand cover, the humus profile was characterized by the absence of the $\mathrm{OH}$ horizon and a deep and dark yellow A horizon (mull-like moder humus; Kubiëna 1953). In the latter case the soils were always podzols or at least podzolic soils (Bouchon et al. 1973); the other soils have been described as varying from leached acidic (mostly represented in shallow sand overlying limestone) to ochrous podzolic (mostly represented in shallow sand overlying sandstone).

The analysis of variance of morphological features (Table 3) indicated that while the OL and OF horizons were not discriminant the $\mathrm{OH}$ horizon was thicker on sandstone and the depth of the A horizon was higher on a deep sand cover, this feature being accompanied by a weaker presence of white-rot fungi. According to the Munsell code, the A horizon was redder on sandstone. Munsell hue and chroma were autocorrelated, being higher (lighter and more strongly coloured A horizon) on shallow sand cover overlying limestone. Thus most 
traits depicted by correspondence analysis seemed to discriminate significantly between the three geomorphological groups.

Earthworm communities differed significantly between these three groups (Table 3). Total earthworm biomasses followed a decreasing order from the shallow sand cover overlying limestone to the deep one and last to the thin sand cover overlying sandstone, but total densities were higher in the middle case. This latter phenomenon was mainly due to the increased abundance of litter-dwelling species, except Lumbricus castaneus. The soil-dwelling species Allolobophora chlorotica, Aporrectodea caliginosa, and Lurnbricus terrestris followed a similar order, being absent on sandstone and present but to a lesser extent on deep sand cover with limestone. The only species (excluding rare species) that seemed ubiquitous between the three groups was the litter-dwelling Lurnbricus castaneus, which was nevertheless more abundant on a deep sand cover with limestone. Thus shallow sand sites with limestone were characterized by the presence and the dominance of soil-dwelling species (mainly Lumbricus terrestris and Aporrectodea caliginosa), deep sand sites with limestone by the presence and the dominance of litter-dwelling species. These two groups contained the two ecological categories of earthworms but in a different ratio. Sandstone was characterized by the near absence of earthworms, except the litter-dwelling Lurnbricus castaneus.

The shallow sand cover $(50-100 \mathrm{~cm})$ overlying limestone was thus characterized by an acid mull humus with a complete earthworm community (both litter- and soil-dwelling species) and fairly good incorporation of litter. The structure of the A horizon was crumby at the time of full earthworm activity (spring, autumn), but this structure was unstable throughout the year given the absence of clay particles (Robin 1979) and the rapid mineralization of organic matter (Lemée 1967, 1978), both important agents stabilizing earthworm aggregates (Shipitalo and Protz 1989). The thick sand cover (more than $1 \mathrm{~m}$ ) overlying limestone was characterized by the presence of a mull-like moder, with an earthworm community dominated by litter-dwelling species. The $\mathrm{OH}$ horizon was absent and the incorporation of litter was not as efficient as in the shallow sand cover. The behaviour of the so-called litter-dwelling species, which have been observed to burrow through the sandy A horizon (highly porous because of the even particle size), might explain the absence of an accumulation layer of holorganic faecal material. Mineralization was not so good (Lemée 1967, 1978), which might explain the darker A horizon. When limestone was absent, with the sand cover directly overlying a sandstone layer, the humus form was of the moder 
type, with a near absence of earthworm species. The $\mathrm{OH}$ horizon was present. The A horizon was dark, as in the thick sand cover over limestone, but its ground colour was red, perhaps due to a more intense mobilization of iron (Toutain and Duchaufour 1970; Delecour 1972).

Influence of the forest cycle

This effect was tested using three groups, the mature stage (biostasis), the tree-fall gaps (zero-event), and the pole stage (aggradation). Only the shallow sand cover with limestone was used for this study, given the restricted area covered by the other two geomorphological types. Table 4 indicates that the main effect on humus profiles was in the depth of the A horizon and to a lesser extent (although significant) in the thickness of the OL and OF horizons. The depth of the A horizon fell sharply after a gap had been created (reduced to about one-half), while the OL and OF horizons remained unchanged. Thus a considerable lack of organic matter occurred in the surface horizons of the soil within 2 years. The development of a new tree stand (aggradation phase) was accompanied by an increase in the thickness of the OL and OF horizons, the depth of the A horizon remaining unchanged. Thus an accumulation process occurred, but only in the litter. Maturation of the stand was characterized by a strong decrease in the thickness of the OL (reduced to one-half) and OF (reduced to one-third) horizons and an increase in the depth of the A horizon. Thus incorporation of litter was better under adult trees (Fig. 2). The OH horizon was nearly absent throughout the forest cycle and no significant change was observed in the colour parameters of the A horizon. However, although changes in the thickness of the $\mathrm{OH}$ horizon and colour of the A horizon were far more pronounced according to geomorphology, the forest cycle had a more marked influence on the thickness of the OL and OF horizons and depth of the A horizon.

These results were reflected in changes in earthworm communities (Table 4). The total number of earthworms decreased after a tree-fall gap occurred; the number of litter-dwelling worms was reduced to one-half (insignificant, due to a high inter-sample variation) while the number of soil-dwelling worms was decreased to one-third (highly significant). The species that contributed most to the decrease in soil-dwelling populations was Aporrectodea longa, a true anecic species (Bouché 1972). Its density dropped to one-tenth. Other soil-dwelling species decreased but not significantly. The growth phase of the beech stand was not accompanied by significant changes in earthworm communities, except for a threefold increase in Dendrodrilus rubidus populations (a 
litterdwelling species). The dominant litter-dwelling Lumbricus castaneus increased, too, but only slightly. Maturation of the stand was characterized by a doubling in total earthworm numbers. Soil-dwelling species were principal contributors, increasing fourfold, the most striking being Aporrectodea longa (20-fold). Densities of litter-dwelling species remained stable overall, but those of Dendrodrilus rubidus decreased sharply to one-third. These changes were visible on biomass measurements (Table 4) but most were less significant, given the high variability of the weight of individual worms (mainly due to variations in age). An exception was the increase in biomass of Allolobophora chlorotica (soil-dwelling) during maturation of the beech stand, which was not reflected in numbers. This indicated that the individuals were bigger in the last phase of the forest cycle.

Thus no change in the humus type was observed, contrary to findings in spruce forests at the higher montane level (Bernier and Ponge 1993, 1994; Ponge et al. 1994), but quantitative changes occurred in some important soil features. Two years after a tree-fall gap had been created a strong fall in the depth of the A horizon and maintenance of the thickness of the litter layers (OL and OF horizons, $\mathrm{OH}$ being absent) despite the lack of litter input were observed. These changes were accompanied by a sharp decline in earthworm populations, which was more important for soil- than for litter-dwelling species. In particular, these changes applied to soils with a poor ground vegetation. Since that time we have observed (unpublished data, 1994) that the fate of the humus profile was highly dependent on the appearance of a graminaceous cover (mainly Melica uniflora). In the absence of grasses the A horizon seems more compact and darker than in their presence. These features were observed previously on the same site by Lemée (1975) and Faille (1977b) after wind storms in 1967. The disappearance of organic matter in the topsoil (deduced from the fall in depth of the A horizon) could be due to mineralization or to leaching. Climate conditions were different in the gaps, with higher temperature maxima and a higher water content in the top horizons (Pontailler 1979); thus more intense mineralization may be expected, even in the absence of ground vegetation. This effect might be reinforced by reduced inputs of organic matter from the litter layers, which remained untouched by earthworms as judged by the constancy of their thickness. An increase in leaching might be expected, too, due to an increase in incident rain and a fall in the activity of soil-dwelling earthworm populations (as long as there was no ground vegetation). Changes in soil conditions and in biological activity following dear-cutting have been measured repeatedly, but an examination of the literature did not give a clear picture of what might happen in the absence of understory vegetation or slash burning. Considering only the effects of the absence of litterfall (and not climatic effects due to the absence of a canopy cover), we compared 
these results with experimental effects of litter deprivation on a similar humus type (David et al. 1991). These authors, too, observed a sharp decline in earthworm populations.

During the growth phase of the beech stand we observed an accumulation of organic matter at the ground surface (increase in the thickness of the OL and more of the OF horizon, but no build-up of and $\mathrm{OH}$ layer) without any significant change either in the A horizon or in earthworm populations. It is remarkable that the increase in litter input was not followed by an increase in earthworm populations, that relied on litter or products derived from litter for their food. In this case, too, we compared these results with those from an experimental increase in litterfall, which did not result in any increase in litter-feeding earthworm populations but in a quite similar accumulation of OL and OF litter (David et al. 1991). The question is whether the earthworm populations reached saturation point with the increase in food or whether there were other factors. In this case positive effects, e.g., an increase in food resources and habitat, might be counterbalanced by negative effects such as impoverishment and acidification of mineral soil horizons. The improved humus conditions (increase in the depth of the A horizon, decrease in the thickness of the OL and OF horizons) observed under adult trees might be an argument in favour of the second hypothesis.

Earthworm populations (mainly soil-dwelling) were stimulated to a large extent by cessation of tree growth (adult stage). Since foliage production per unit ground surface did not seem to be affected by the passage from the pole to the adult stage (Lemée 1978), the principal changes must occur in the soil system. Current knowledge of nutrient cycles in tree plantations of varying age (Miller 1984), especially the translocation of nutrients from older to younger tissues in adult trees, suggests that nutrient uptake by trees in the soil system might decrease once growth has ceased. Thus the laws outlined by Ulrich (1984) for the establishment, steady state and destruction of whole forest ecosystems may be applied to a forest cycle. In particular, the phase of humus disintegration that accompanies the (postulated) death of forest ecosystems closely resembles the improvement in humus conditions and the enrichment of earthworm communities observed under adult trees in the present study. Similar findings have been reported previously for virgin forests (Page 1974) and man-made forests grown to the adult stage (Bernier and Ponge 1993, 1994; Ponge et al. 1994), and thus seems to be a general law of the forest cycle, at least for climax species that are not tolerant of humus conditions, such as spruce or beech. 


\section{Conclusion}

Whether humus profiles and soil animal communities are better indicators of site quality than a simple list of plant species is not the question we sought to answer in the present study. However, in the light of our results and as pointed out by Miles (1985), these features are key components of terrestrial ecosystems and therefore need to be studied not only as passive but also as active agents of ecosystem dynamics.

Acknowledgements This work was carried out with financial support from the French National Office of Forests. We thank Prof. G. Lemée and his collaborators for the results they accumulated on this site which were an essential basis for the present work. We also thank Prof. D.C. Coleman (Athens, Georgia) for revising the language.

\section{References}

AFES (1992) Référentiel pédologique. Principaux sols d'Europe. INRA, Paris

Arpin P, Ponge JF, Dabin B, Mori A (1984) Utilisation des Nématodes Mononchida et des Collemboles pour caractériser des phénomènes pédobiologiques. Rev Ecol Biol Sol 21:243-268

Bernier N (1992) Modification de la forme d'humus au cours du cycle sylvogénétique d'une pessière d'altitude. DEA Memoir, University of Orsay

Bernier N, Ponge JF (1993) Dynamique et stabilité des humus au cours du cycle sylvogénétique d'une pessière d'altitude. CR Acad Sci Paris Sci Vie 316:647-651

Bernier N, Ponge JF (1994) Humus form dynamics during the sylvogenetic cycle in a mountain spruce forest. Soil Biol Biochem 26:183-220

Bernier N, Ponge JF, André J (1993) Comparative study of soil organic layers in two bilberry-spruce forest stands 
(Vaccinio-Piceetea). Relation to forest dynamics. Geoderma 59:89-108

Bouché MB (1972) Lombriciens de France. Ecologie et systématique. INRA, Paris

Bouchon J, Faille A, Lemée G, Robin AM, Schmitt A (1973) Cartes et notice des sols, du peuplement forestier et des groupements végétaux de la réserve biologique de la Tillaie en forêt de Fontainebleau. Université d'Orsay, Orsay

David JF, Ponge JF, Arpin P, Vannier G (1991) Reactions of the macrofauna of a forest mull to experimental perturbations of litter supply. Oikos 61:316- 326

Delecour F (1972) Problèmes généraux de complexation organo-minérale dans les sols bruns ardennais. Pédologie 22:185-197

Duchaufour P (1980) Ecologie de l'humification et pédogénèse des sols forestiers. In: Pesson P (ed) Actualités d'écologie forestière. Gauthier-Villars, Paris, pp 177-201

Duchaufour P (1991) Pédologie: sol, végétation, environnement. Masson, Paris

Faille A (1975a) Recherches sur les écosystèmes des réserves biologiques de la forêt de Fontainebleau. V. Evolution à court terme des humus à la suite de l'ouverture de clairières. Oecol Plant 10:43-62

Faille A (1975b) Recherches sur les écosystèmes des réserves biologiques de la forêt de Fontainebleau. VI. Influence tardive du clairiérage sur les humus. Oecol Plant 10:309-330

Faille A (1977a) Action des peuplements de Calamagrostis epigeios (L.) Roth, dans la dynamique des écosystèmes de la forêt de Fontainebleau. I. Rôle dans le cycle de la matière organique et des bioéléments majeurs. Bull Ecol 8:11-21

Faille A (1977b) Action des peuplements de Calamagrostis epigeios (L.) Roth, dans la dynamique des écosystèmes de la forêt de Fontainebleau. II. Influence sur quelques caractères des humus et leurs activités microbiennes. Rev Ecol Biol Sol 14:289-306

Faille A, Lemée G, Pontailler JY (1984a) Dynamique des clairières d'une forêt inexploitée (réserves biologiques de la forêt de Fontainebleau). I. Origine et état actuel des ouvertures. Acta Oecol Oecol Gen 5:35-51 
Faille A, Lemée G, Pontailler JY (1984b) Dynamique des clairières d'une forêt inexploitée (réserves biologiques de la forêt de Fontainebleau). II. Fermeture des clairières actuelles. Acta Oecol Oecol Gen 5:181-199

Greenacre MJ (1984) Theory and applications of correspondence analysis. Academic Press, London

Guillet B, Robin AM (1972) Interprétation de datations par le ${ }^{14} \mathrm{C}$ d'horizons Bh de deux podzols humoferrugineux, l'un formé sous callune, l'autre sous chênaie-hêtraie. CR Acad Sci Paris Ser D 274:28592862

Jacquiot C, Robin AM, Bedeneau M (1973) Reconstitution d'un ancien peuplement forestier en forêt de Fontainebleau par l'étude anatomique de charbons de bois et leur datation par le ${ }^{14} \mathrm{C}$. Bull Soc Bot Fr $120: 231-234$

Koop H, Hilgen P (1987) Forest dynamics and regeneration mosaic shifts in unexploited beech (Fagus sylvatica) stands at Fontainebleau (France). For Ecol Manage 20:135-150

Kubiëna WL (1953) The soils of Europe. Illustrated diagnosis and systematics. CSIC, Madrid

Lemée G (1967) Investigations sur la minéralisation de l'azote et son évolution annuelle dans des humus forestiers in situ. Oecol Plant 2:285-324

Lemée G (1975) Recherches sur les écosystèmes des réserves biologiques de la forêt de Fontainebleau. III. Influence du peuplement graminéen sur les caractères et l'activité biologique du mull acide. Rev Ecol Biol Sol 12:157-167

Lemée G (1978) La hêtraie naturelle de Fontainebleau. In: Lamotte M, Bourlière F (eds) Problèmes d'écologie: structure et fonctionnement des écosystèmes terrestres. Masson, Paris, pp 75-128

Lemée G (1981) Contribution à l'histoire des landes de la forêt de Fontainebleau d'aprbs l'analyse pollinique des sols. Bull Soc Bot Fr 128:189-200

Lemée G (1985) Rôle des arbres intolérants à l'ombrage dans la dynamique d'une hêtraie naturelle (forêt de Fontainebleau). Acta Oecol Oecol Plant 6:3-20

Lemée G (1987a) Dynamique de fermeture par régénération et évolution morphométrique du hêtre dans les vides 
d'une forêt non exploitée (réserves biologiques de la forêt de Fontainebleau). Bull Ecol 18:1-11

Lemée G (1987b) Les populations de chênes (Quercus petraea Liebl.) des réserves biologiques de la Tillaie et du Gros-Fouteau en forêt de Fontainebleau: structure, démographie, évolution. Rev Ecol Biol Sol 42:329355

Lemée G (1989) Structure et dynamique de la hêtraie des réserves biologiques de la forêt de Fontainebleau: un cas de complexe climacique de forêt feuillue monospécifique tempérée. Acta Oecol Oecol Gen 10:155174

Lemée G, (1990a) Les réserves biologiques de la Tillaie et du Gros-Fouteau en forêt de Fontainebleau, écocomplexes climaciques. Bull Soc Bot Fr 137:47-62

Lemée G (1990b) Evolution du paysage dans la forêt de Fontainebleau au cours des cinq derniers millénaires. Bull Ecol 21:119-127

Miles J (1985) Soil in the ecosystem. In: Fitter AH (ed) Ecological interactions in soil. Plants, microbes and animals. Blackwell, Oxford, pp 407-427

Miller HG (1984) Dynamics of nutrient cycling in plantation ecosystems. In: Bowen GD, Nambiar EKS (eds) Nutrition of forest trees in plantations. Academic Press, London, pp 53-78

Oldeman RAA (1990) Forests: elements of silvology. Springer, Berlin Heidelberg New York

Page G (1968) Some effects of conifer crops on soil properties. Commonw For Rev 47:52-62

Page G (1974) Effects of forest cover on the properties of some Newfoundland forest soils. Can For Serv Publ No. 1332

Ponge JF, André J, Bernier N, Gallet C (1994) La régénération naturelle: connaissances actuelles. Le cas de l'épicéa en forêt de Macot (Savoie). Rev For Fr 46:25-45

Pontailler JY (1979) La régénération du hêtre en forêt de Fontainebleau. Doctorate thesis, University of Orsay (unpublished) 
Robin AM (1970) Contribution à l'étude du processus de podzolisation sous forêt de feuillus. Sci Sol [1970] 6383

Robin AM (1979) Genèse et évolution des sols podzolisés sur affleurements sableux du Bassin Parisien. Doctorate thesis, University of Orsay (unpublished)

Rohlf FJ, Sokal RR (1969) Statistical tables. Freeman, San Francisco

Shipitalo M J, Protz R (1989) Chemistry and micromorphology of aggregation in earthworm casts. Geoderma 45:357-374

Sims RW, Gerard BM (1985) Earthworms. Keys and notes for the identification and study of the species. Brill and Backhuys, London

Sokal RR, Rohlf FJ (1969) Biometry. The principles and practice of statistics in biological research. Freeman, San Francisco

Toutain F (1981) Les humus forestiers. Structures et modes de fonctionnement. Rev For Fr 33:449-477

Toutain F (1987) Activité biologique des sols, modalités et lithodépendance. Biol Fertil Soils 3:31-38

Toutain F, Duchaufour P (1970) Etude comparée des bilans biologiques de certains sols de hêtraie. Ann Sci For 27:39-61

Ulrich B (1984) Ion cycle and forest ecosystem stability. In: Ågrén GI (ed) State and change of forest ecosystems. Indicators in current research. Swed Univ Agric Sci, Uppsala, Dep Ecol Environ Res, Rep No. 13, pp 207-233

Van Baren B, Hilgen P (1984) Structuur en dynamiek de La Tillaie, een ongestoord beukenbos in her bosgebied van Fontainebleau. Doctorate thesis, University of Leersum (unpublished)

Weissen F (1979) La régénération naturelle de l'épicéa en Ardenne. Bull Soc R For Belg 86:115-123

Weissen F (1986) Problèmes de régénération en hêtraie ardennaise. Bull Soc R For Belg 93:113-117

Weissen F, Delecour F, Dethioux M (1986) Problèmes de régénération en hêtraie ardennaise: propositions de 
traitements pour les hêtraies difficiles à régénérer naturellement. Bull Soc R For Belg 93:161-166 


\section{Legends of figures}

Fig. 1 Analysis of correspondences ( $30 \times 90$ samples, $14 \times 2=28$ measurements), projection in the plane of the two first axes $(\mathrm{OL}, \mathrm{OF}, \mathrm{OH}$ thickness of the OL, OF, OH horizons, $A$ depth of the A horizon, WR whiterot fungi in the OF horizon, CO3 CO6 CO9 Munsell colour of the A horizon at 3, 6, $9 \mathrm{~cm}$ beneath the O horizon, $\mathrm{CH} 3$, $\mathrm{CH} 6, \mathrm{CH} 9$ idem for Munsell chroma; VA 3,VA 6, VA 9 idem for Munsell hue, + and denote higher and lower value for a given measurement, respectively) 
Table 1 Vegetation and soil features of the 30 study sites. Trees are beech unless otherwise indicated

\begin{tabular}{|c|c|c|c|c|}
\hline Site & Phase of the forest cycle & Soil & Sand cover & Limestone \\
\hline 1 & Tree-fall gap (zero-event) & Leached acidic & Thin & Present \\
\hline 2 & Pole stage 45 years (aggradation) & Leached acidic & Thin & Present \\
\hline 3 & Full-grown stage (biostasis) & Leached acidic & Thin & Present \\
\hline 4 & Tree-fall gap (zero-event) & Leached acidic & Thin & Present \\
\hline 5 & Pole stage 35 years (aggradation) & Leached acidic & Thin & Present \\
\hline 6 & Senescent individual oak & Leached acidic & Thin & Present \\
\hline 7 & Bracken heath (collapse) & Ochrous podzolic & Thin & Absent \\
\hline 8 & Sparse beech (20 years) + bracken & Ochrous podzolic & Thin & Absent \\
\hline 9 & Pole stage 20 years (aggradation) & Leached acidic & Thin & Present \\
\hline 10 & Pole stage 45 years (aggradation) & Leached podzolic & Thin & Present \\
\hline 11 & Pole stage 20 years (aggradation) & Ochrous podzolic & Thin & Present \\
\hline 12 & Tree-fall gap (zero-event) & Leached podzolic & Thin & Present \\
\hline 13 & Full-grown stage (biostasis) & Leached acidic & Thin & Present \\
\hline 14 & Gap filled by adjacent trees & Leached acidic & Thin & Present \\
\hline 15 & Sapling stage 15 years (innovation) & Ochrous podzolic & Thin & Present \\
\hline 16 & Senescent individual oak & Podzol & Thick & Present \\
\hline 17 & Bracken heath (collapse) & Podzol & Thick & Present \\
\hline 18 & Pole stage 25 years (aggradation) & Podzolic & Thick & Present \\
\hline 19 & Full-grown stage (biostasis) & Podzol & Thick & Present \\
\hline 20 & Gap filled by adjacent trees & Podzol & Thick & Present \\
\hline 21 & Clonal suckers & Podzol & Thick & Present \\
\hline 22 & Tree-fall gap (zero-event) & Podzolic & Thick & Present \\
\hline 23 & Pole stage 45 years (aggradation) & Podzol & Thick & Present \\
\hline 24 & Gap filled by adjacent trees & Podzolic & Thick & Present \\
\hline 25 & Full-grown stage (biostasis) & Podzolic & Thin & Absent \\
\hline 26 & Gap filled by adjacent trees & Podzolic & Thin & Absent \\
\hline 27 & Gap filled by adjacent trees & Leached podzolic & Thin & Absent \\
\hline 28 & Bracken heath & Podzolic & Thin & Absent \\
\hline 29 & Full-grown stage (biostasis) & Ochrous podzolic & Thin & Absent \\
\hline 30 & Pole stage 45 years (aggradation) & Ochrous podzolic & Thin & Present \\
\hline
\end{tabular}


Table 2 List of the 11 earthworms species present in the sites investigated

\begin{tabular}{ll}
\hline Habitat & Species \\
\hline Soil & Allolobophora chlorotica (Savigny, 1826) \\
Soil & Aporrectodea caliginosa (Savigny, 1826) \\
Soil & Aporrectodea longa (Ude, 1885) \\
Litter & Dendrobaena octaedra (Savigny, 1826) \\
Litter & Dendrobaena pygmaea (Savigny, 1826) \\
Litter & Eisenia fetida (Savigny, 1826) \\
Litter & Lumbricus castaneus (Savigny, 1826) \\
Litter & Lumbricus eiseni (Levinsen, 1884) \\
Soil & Lumbricus terrestris (Linnaeus, 1758) \\
Soil & Octolasion cyaneum (Savigny, 1826) \\
\hline
\end{tabular}


Table 3 Analysis of variance according to geomorphology with morphological measurements of humus profiles and earthworm communities

\begin{tabular}{|c|c|c|c|c|c|}
\hline & F ratio & Probability & $\begin{array}{l}\text { Shallow sand } \\
\text { limestone }\end{array}$ & $\begin{array}{l}\text { Deep sand } \\
\text { limestone }\end{array}$ & $\begin{array}{l}\text { Shallow sand } \\
\text { sandstone }\end{array}$ \\
\hline \multicolumn{6}{|l|}{ Humus profile } \\
\hline OL thickness $(\mathrm{cm})$ & 0.21 & $0.82 \mathrm{NS}$ & 1.80 & 1.64 & 1.65 \\
\hline OF thickness (cm) & 2.05 & $0.13 \mathrm{NS}$ & 1.36 & 1.60 & 1.97 \\
\hline OH thickness $(\mathrm{cm})$ & 14.18 & $0.0000 * * *$ & $0.06 \mathrm{~b}$ & $0.04 \mathrm{~b}$ & $0.41 \mathrm{a}$ \\
\hline A depth $(\mathrm{cm})$ & 6.69 & $0.0021 * *$ & $6.71 \mathrm{~b}$ & $8.37 \mathrm{a}$ & $6.02 \mathrm{~b}$ \\
\hline Presence of white-rot & 4.84 & $0.010 *$ & $0.67 \mathrm{a}$ & $0.37 \mathrm{~b}$ & $0.76 \mathrm{a}$ \\
\hline Munsell colour at $3 \mathrm{~cm}$ & 44.47 & $0.0000 * * *$ & $10.0 \mathrm{YRa}$ & $10.0 \mathrm{YRa}$ & $7.1 \mathrm{YRb}$ \\
\hline Munsell colour at $6 \mathrm{~cm}$ & 43.55 & $0.0000 * * *$ & 10.0 YRa & $10.0 \mathrm{YRa}$ & $7.1 \mathrm{YRb}$ \\
\hline Munsell colour at $9 \mathrm{~cm}$ & 48.01 & $0.0000 * * *$ & $10.0 \mathrm{YRa}$ & $10.0 \mathrm{YRa}$ & $7.1 \mathrm{YRb}$ \\
\hline Munsell hue at $3 \mathrm{~cm}$ & 11.47 & $0.0001 * * *$ & $4.1 / \mathrm{a}$ & $3.0 / \mathrm{b}$ & $3.3 / \mathrm{b}$ \\
\hline Munsell hue at $6 \mathrm{~cm}$ & 7.56 & $0.0011 * *$ & $4.6 / \mathrm{a}$ & $3.9 / \mathrm{b}$ & $4.2 / \mathrm{b}$ \\
\hline Munsell hue at $9 \mathrm{~cm}$ & 0.31 & $0.74 \mathrm{NS}$ & $5.1 /$ & $4.9 /$ & $5.1 /$ \\
\hline Munsell chroma at $3 \mathrm{~cm}$ & 14.29 & $0.0000 * * *$ & $/ 1.7 \mathrm{a}$ & $/ 1.1 \mathrm{~b}$ & $/ 1.1 \mathrm{~b}$ \\
\hline Munsell chroma at $6 \mathrm{~cm}$ & 13.63 & $0.0000 * * *$ & $/ 2.0 \mathrm{a}$ & $/ 1.2 \mathrm{~b}$ & $/ 1.5 \mathrm{~b}$ \\
\hline Munsell chroma at $9 \mathrm{~cm}$ & 10.12 & $0.0001 * * *$ & $/ 2.6 \mathrm{a}$ & $/ 1.8 \mathrm{~b}$ & $/ 2.4 \mathrm{a}$ \\
\hline \multicolumn{6}{|c|}{ Earthworm density (number $\mathrm{m}^{-2}$ ) } \\
\hline Total earthworms & 12.51 & $0.0000 * * *$ & $17.04 \mathrm{a}$ & $20.61 \mathrm{a}$ & $7.02 \mathrm{~b}$ \\
\hline Total litter-dwelling & 9.49 & $0.0002 * * *$ & $9.25 \mathrm{~b}$ & $16.75 \mathrm{a}$ & $6.84 \mathrm{~b}$ \\
\hline Total soil-dwelling & 22.85 & $0.0000 * * *$ & $6.05 \mathrm{a}$ & $3.11 \mathrm{~b}$ & $0.06 \mathrm{c}$ \\
\hline Allolobophora chlorotica & 6.34 & $0.0024 * *$ & $0.69 \mathrm{a}$ & $0.06 \mathrm{~b}$ & $0.00 \mathrm{~b}$ \\
\hline Aporrectodea caliginosa & 14.68 & $0.0000 * * *$ & $3.31 \mathrm{a}$ & $1.76 b$ & $0.00 \mathrm{c}$ \\
\hline Aporrectodea longa & 2.57 & $0.077 \mathrm{NS}$ & 0.50 & 0.10 & 0.00 \\
\hline Dendrobaena octaedra & 20.92 & $0.0000 * * *$ & $0.46 b$ & $3.00 \mathrm{a}$ & $0.70 \mathrm{~b}$ \\
\hline Dendrobaena pygmaea & 7.76 & $0.0007 * * *$ & $0.50 \mathrm{~b}$ & $1.74 \mathrm{a}$ & $0.32 b$ \\
\hline Dendrodrilus rubidus & 8.23 & $0.0005 * * *$ & $2.70 \mathrm{a}$ & $3.94 \mathrm{a}$ & $0.97 \mathrm{~b}$ \\
\hline Lumbricus castaneus & 0.62 & $0.55 \mathrm{NS}$ & 4.77 & 6.09 & 4.91 \\
\hline Lumbricus terrestris & 8.94 & $0.0003 * * *$ & $1.73 \mathrm{a}$ & $0.98 \mathrm{a}$ & $0.06 b$ \\
\hline Octolasion cyaneum & 0.57 & $0.57 \mathrm{NS}$ & 0.06 & 0.00 & 0.00 \\
\hline \multicolumn{6}{|l|}{ Earthworm biomass $\left(\mathrm{g} \mathrm{m}^{-2}\right)$} \\
\hline Total earthworms & 15.13 & $0.0000 * * *$ & $3.96 \mathrm{a}$ & $2.55 \mathrm{~b}$ & $0.91 \mathrm{c}$ \\
\hline Total litter-dwelling & 1.84 & $0.16 \mathrm{NS}$ & 1.06 & 1.33 & 0.89 \\
\hline Total soil-dwelling & 17.55 & $0.0000 * * *$ & $2.73 a$ & $1.22 b$ & $0.02 \mathrm{c}$ \\
\hline Allolobophora chlorotica & 4.05 & $0.019 *$ & $0.18 \mathrm{a}$ & $0.02 \mathrm{~b}$ & $0.00 \mathrm{~b}$ \\
\hline Aporrectodea caliginosa & 12.07 & $0.0000 * * *$ & $1.11 \mathrm{a}$ & $0.54 \mathrm{~b}$ & $0.00 \mathrm{c}$ \\
\hline Aporrectodea longa & 3.89 & $0.022 *$ & $0.25 \mathrm{a}$ & $0.01 \mathrm{~b}$ & $0.00 \mathrm{~b}$ \\
\hline Dendrobaena octaedra & 9.54 & $0.0002 * * *$ & $0.03 b$ & $0.16 \mathrm{a}$ & $0.07 \mathrm{~b}$ \\
\hline Dendrobaena pygmaea & 7.78 & $0.0007 * * *$ & $0.01 \mathrm{~b}$ & $0.06 \mathrm{a}$ & $0.01 \mathrm{~b}$ \\
\hline Dendrodrilus rubidus & 6.09 & $0.0029 * *$ & $0.35 \mathrm{a}$ & $0.43 \mathrm{a}$ & $0.10 \mathrm{~b}$ \\
\hline Lumbricus castaneus & 0.02 & $0.98 \mathrm{NS}$ & 0.68 & 0.69 & 0.71 \\
\hline Lumbricus terrestris & 7.43 & $0.0009 * * *$ & $1.27 \mathrm{a}$ & $0.59 \mathrm{~b}$ & $0.02 \mathrm{~b}$ \\
\hline Octolasion cyaneum & 0.57 & $0.57 \mathrm{NS}$ & 0.06 & 0.00 & 0.00 \\
\hline
\end{tabular}

${ }^{*} \mathrm{p}<0.05, * * \mathrm{p}<0.01, * * * \mathrm{p}<0.001$. Means from the same homogeneous group (SNK procedure) are followed by the same letter, $d f 2 / 87$ for humus profiles, $2 / 177$ for earthworms 
Table 4 Analysis of variance according to phases of the forest cycle, with morphological measurements of humus profiles and earthworm communities

\begin{tabular}{|c|c|c|c|c|c|}
\hline & F ratio & Probability & Mature stage & Tree-fall gap & Pole stage \\
\hline \multicolumn{6}{|l|}{ Humus profile } \\
\hline OL thickness $(\mathrm{cm})$ & 3.44 & $0.044 *$ & $1.21 \mathrm{~b}$ & $1.38 \mathrm{~b}$ & $2.44 \mathrm{a}$ \\
\hline OF thickness $(\mathrm{cm})$ & 4.52 & $0.019 *$ & $0.67 \mathrm{~b}$ & $0.92 \mathrm{~b}$ & $2.03 \mathrm{a}$ \\
\hline OH thickness $(\mathrm{cm})$ & 1.28 & $0.29 \mathrm{NS}$ & 0.00 & 0.03 & 0.13 \\
\hline A depth $(\mathrm{cm})$ & 26.92 & $0.0001 * * *$ & $11.58 \mathrm{a}$ & $5.28 \mathrm{~b}$ & $5.97 \mathrm{~b}$ \\
\hline Presence of white-rot & 1.36 & $0.27 \mathrm{NS}$ & 1.00 & 0.67 & 0.83 \\
\hline Munsell colour at $3 \mathrm{~cm}$ & 0.00 & $1.00 \mathrm{NS}$ & $10.0 \mathrm{YR}$ & $10.0 \mathrm{YR}$ & $10.0 \mathrm{YR}$ \\
\hline Munsell colour at $6 \mathrm{~cm}$ & 0.00 & $1.00 \mathrm{NS}$ & $10.0 \mathrm{YR}$ & $10.0 \mathrm{YR}$ & $10.0 \mathrm{YR}$ \\
\hline Munsell colour at $9 \mathrm{~cm}$ & 0.00 & $1.00 \mathrm{NS}$ & $10.0 \mathrm{YR}$ & $10.0 \mathrm{YR}$ & $10.0 \mathrm{YR}$ \\
\hline Munsell hue at $3 \mathrm{~cm}$ & 1.29 & $0.29 \mathrm{NS}$ & $4.5 /$ & $3.8 /$ & $3.9 /$ \\
\hline Munsell hue at $6 \mathrm{~cm}$ & 1.62 & $0.21 \mathrm{NS}$ & $4.5 /$ & $4.2 /$ & $4.8 /$ \\
\hline Munsell hue at $9 \mathrm{~cm}$ & 3.28 & $0.051 \mathrm{NS}$ & $4.5 /$ & $4.7 /$ & $5.4 /$ \\
\hline Munsell chroma at $3 \mathrm{~cm}$ & 2.92 & $0.068 \mathrm{NS}$ & $/ 2.2$ & $/ 1.8$ & $/ 1.4$ \\
\hline Munsell chroma at $6 \mathrm{~cm}$ & 0.52 & $0.61 \mathrm{NS}$ & $/ 2.0$ & $/ 1.8$ & $/ 2.1$ \\
\hline Munsell chroma at $9 \mathrm{~cm}$ & 2.70 & $0.082 \mathrm{NS}$ & $/ 2.0$ & $/ 2.3$ & $/ 2.9$ \\
\hline \multicolumn{6}{|c|}{ Earthworm density (number $\mathrm{m}^{-2}$ ) } \\
\hline Total earthworms & 3.49 & $0.036 *$ & $31.24 \mathrm{a}$ & $11.78 \mathrm{~b}$ & $16.28 \mathrm{~b}$ \\
\hline Total litter-dwelling & 2.82 & $0.065 \mathrm{NS}$ & 9.09 & 4.81 & 10.16 \\
\hline Total soil-dwelling & 5.61 & $0.0058 * *$ & $18.60 \mathrm{a}$ & $6.28 b$ & $4.36 \mathrm{~b}$ \\
\hline Allolobophora chlorotica & 2.44 & $0.093 \mathrm{NS}$ & 1.98 & 0.96 & 0.37 \\
\hline Aporrectodea caliginosa & 2.14 & $0.12 \mathrm{NS}$ & 6.21 & 4.28 & 2.32 \\
\hline Aporrectodea longa & 7.11 & $0.0018 * *$ & $3.25 \mathrm{a}$ & $0.32 \mathrm{~b}$ & $0.16 \mathrm{~b}$ \\
\hline Dendrobaena octaedra & 0.78 & $0.47 \mathrm{NS}$ & 0.24 & 0.00 & 0.24 \\
\hline Dendrobaena pygmaea & 0.16 & $0.85 \mathrm{NS}$ & 0.24 & 0.49 & 0.41 \\
\hline Dendrodrilus rubidus & 4.59 & $0.014 *$ & $1.72 \mathrm{~b}$ & $1.57 \mathrm{~b}$ & $4.59 \mathrm{a}$ \\
\hline Lumbricus castaneus & 1.86 & $0.16 \mathrm{NS}$ & 5.08 & 2.07 & 4.63 \\
\hline Lumbricus terrestris & 0.84 & $0.44 \mathrm{NS}$ & 3.23 & 2.07 & 1.70 \\
\hline Octolasion cyaneum & 1.35 & $0.27 \mathrm{NS}$ & 0.00 & 0.32 & 0.00 \\
\hline \multicolumn{6}{|l|}{ Earthworm biomass $\left(\mathrm{g} \mathrm{m}^{-2}\right)$} \\
\hline Total earthworms & 2.43 & $0.094 \mathrm{NS}$ & 7.46 & 3.71 & 3.67 \\
\hline Total litter-dwelling & 2.21 & $0.12 \mathrm{NS}$ & 0.99 & 0.56 & 1.19 \\
\hline Total soil-dwelling & 2.90 & $0.061 \mathrm{NS}$ & 6.21 & 3.00 & 2.27 \\
\hline Allolobophora chlorotica & 3.84 & $0.026 *$ & $0.62 \mathrm{a}$ & $0.23 \mathrm{ab}$ & $0.06 \mathrm{~b}$ \\
\hline Aporrectodea caliginosa & 1.78 & $0.18 \mathrm{NS}$ & 1.70 & 1.42 & 0.76 \\
\hline Aporrectodea longa & 3.70 & $0.030 *$ & $1.06 \mathrm{a}$ & $0.13 b$ & $0.19 \mathrm{~b}$ \\
\hline Dendrobaena octaedra & 1.02 & $0.37 \mathrm{NS}$ & 0.03 & 0.00 & 0.01 \\
\hline Dendrobaena pygmaea & 0.42 & $0.67 \mathrm{NS}$ & 0.00 & 0.02 & 0.01 \\
\hline Dendrodrilus rubidus & 3.68 & $0.030 *$ & $0.19 \mathrm{~b}$ & $0.20 \mathrm{~b}$ & $0.56 \mathrm{a}$ \\
\hline Lumbricus castaneus & 1.04 & $0.36 \mathrm{NS}$ & 0.74 & 0.35 & 0.62 \\
\hline Lumbricus terrestris & 0.74 & $0.49 \mathrm{NS}$ & 2.49 & 1.46 & 1.32 \\
\hline Octolasion cyaneum & 1.35 & $0.27 \mathrm{NS}$ & 0.00 & 0.32 & 0.00 \\
\hline
\end{tabular}

See footnotes to Table 3 


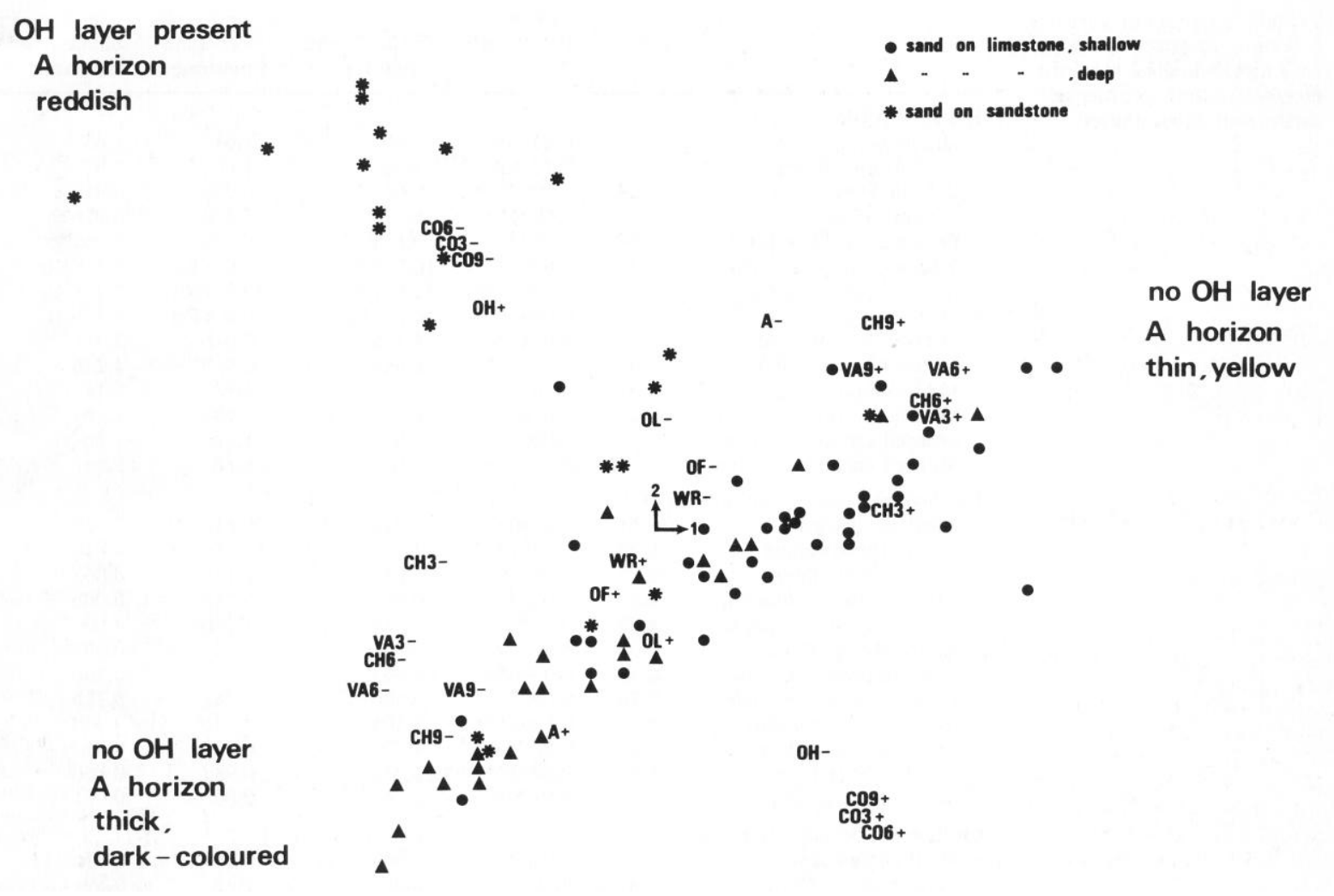

Fig. 1 


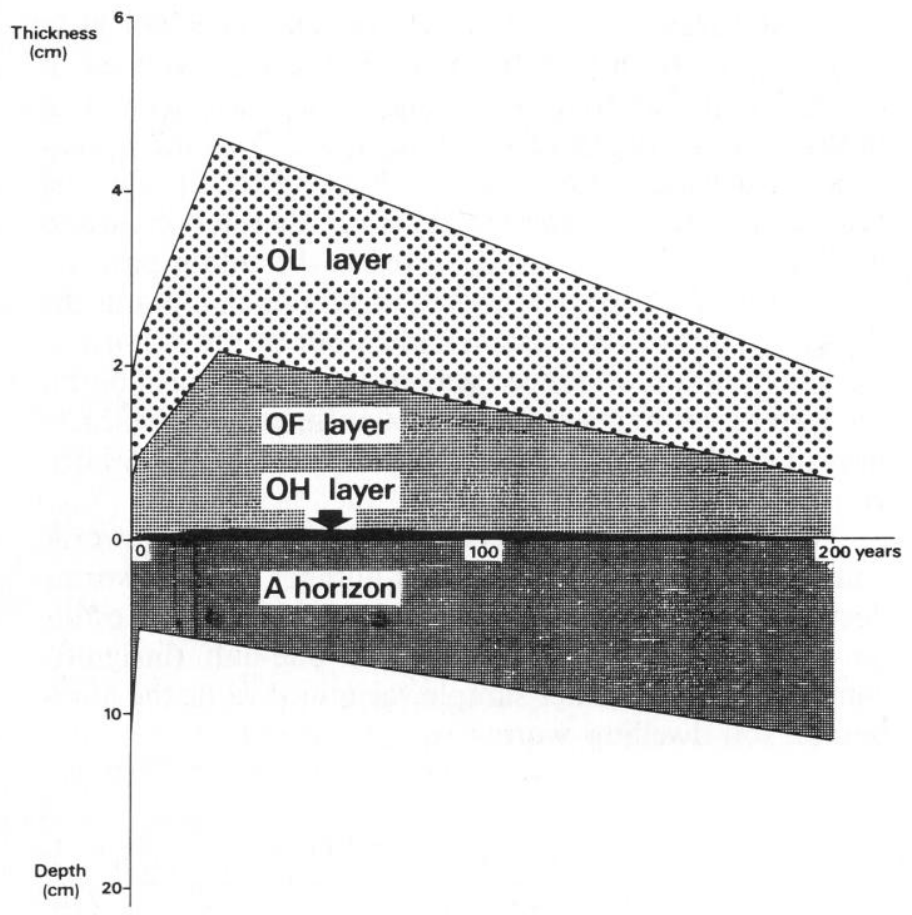

Fig. 2 